Katarzyna Mirgos

InSTYTUt Kultury Europejskiej

UniWERSYTET IM. A. MickiewicZA

KAMIR@AMU.EDU.PL

\title{
MNIEJSZOŚĆ W MNIEJSZOŚCI. IMIGRANCI W BASKIJSKIEJ WSPÓLNOCIE AUTONOMICZNEJ
}

W odniesieniu do zjawisk mających miejsce we współczesnym świecie społecznym badacze kultury zwracają uwagę na współistnienie kil$\mathrm{ku}$ tendencji. $\mathrm{Z}$ jednej strony wciąż mamy do czynienia $\mathrm{z}$ kryzysem państwa narodowego, dążeniem do zniesienia granic, budowaniem tożsamości w opartym na pozanarodowych wzorcach, $\mathrm{z}$ drugiej coraz większe poparcie zyskują tendencje przeciwne, odwołujące się do ideologii narodowej i przedstawiające odmienność kulturową jako zagrożenie ${ }^{1}$. Jednocześnie obserwuje się wzrost samoświadomości grup mniejszościowych, które podkreślają swoją odrębność i działają na rzecz suwerenności. W związku z tymi dążeniami niektórzy autorzy zwracają uwagę na fakt istnienia państwowego nacjonalizmu, wykazującego często agresję w stosunku do zamieszkujących jego terytorium mniejszości [Żelazny, 2000: 221-233, 305 -306; Moreno Cabrera, 2015]. Nowym kulturowym wyzwaniem stają się coraz bardziej intensywne procesy migracyjne, które dodatkowo komplikują ten obraz przyczyniając się zarazem do redefinicji dotychczasowych koncepcji i polityk. W chwili obecnej coraz silniejsze są nastroje antyimigranckie i postulaty „zamknięcia granic” i niewielu jest tych, którzy twierdzą, tak jak Tariq Modood, że w obliczu terroryzmu potrzebujemy „nie mniej, lecz więcej multikulturalizmu" [Modood, 2014: 32]².

1 Thomas Hylland Eriksen zauważył, że „pod wpływem sił nowoczesności i globalizacji ludzie stają się jednocześnie coraz bardziej do siebie podobni i coraz bardziej różni od siebie nawzajem" [Eriksen, 2013: 243].

2 W obliczu wydarzeń, jakich jesteśmy dziś świadkami, a które zdają się być apogeum naszej „epoki migracji” trudno pozostać obojętnym. Część współczesnych antropologów sceptycznie 
Niniejszy tekst opiera się na badaniach prowadzonych przeze mnie w Baskijskiej Wspólnocie Autonomicznej, tak wśród Basków, jak i grup imigranckich ${ }^{3}$. Zjawisko imigracji na tym obszarze ma charakter szczególny, dotyczy bowiem narodu ${ }^{4}$, który stanowi mniejszość w Hiszpanii (co więcej, którego język stanowi mniejszościowy nawet na własnym terytorium), [Atxaga, 2009: 126]. Cennym elementem dla badań baskologicznych jest aspekt nowej, wewnętrznej relacji - postawy mniejszości państwowej wobec nowej mniejszości regionalnej ${ }^{5}$. Warto postawić sobie pytanie, czy grupa mniejszościowa uznająca, że jej własna kultura wymaga wsparcia i ochrony postrzega imigrantów jako kolejne zagrożenie oraz jaki charakter ma w przypadku takiej relacji polityka wobec imigrantów, czy sam proces integracji (dla wielu imigrantów wyzwaniem jest dwukulturowy i dwujęzyczny charakter regionu). Istotne jest tu również uwzględnienie narodowych aspiracji Basków, które interpretowane bywają dwojako. $\mathrm{Z}$ jednej strony podkreślano ich agresywny charakter i brak uzasadnienia [Baglietto, 2004: 120; Díez, 2004: 94-95; González, 2004: 12-13], z drugiej część badaczy wskazywało na raczej obronny wymiar postaw separatystycznych, w tym antyfrankistowski rodowód, czy istnienie nacjonalizmu hiszpańskiego [Moreno Cabrera 2015; Kurlansky 2000, s. 233 i dalsze; Vilar, 1991: 138]. Dziś baskijska tożsamość zbiorowa stoi przed wyzwaniami

odnosi się do możliwości zachowania przez badacza neutralności i konstruowania obiektywnego opisu [Nowicka, 2009: 30-32], a niektórzy nakłaniają do aktywizmu i mówią nie tylko o konieczności zaangażowania się czy współpracy, ale wręcz (tak jak David Graeber czy Jeffrey S. Juris) o antropologii "wojującej” i "anarchistycznej” [Kuligowski, 2012: 39-43; Pomieciński 2012: 144-147]. Interesująca w tym kontekście jest też koncepcja autoetnografii.

3 Zastosowana metodologia była dostosowana do kontekstu badanej sytuacji i konkretnego rozmówcy (w przypadku rozmów z urzędnikami państwowymi był to wywiad sformalizowany, podczas spotkań z imigrantami nierzadko obserwacja uczestnicząca).

4 Posługując się pojęciem narodu odnoszę się do kwestii tożsamości zbiorowej, poczucia wspólnoty narodowej i kulturowej odrębności.

5 Zagadnienie charakteru stosunków Baskami z innymi grupami można pogłębić poprzez przyjrzenie się historycznym mniejszościom występującym na tym terenie (etnicznym lub religijnym). Przykładem są Cyganie i agoci (bask. agotak). Ci pierwsi również obecnie są postrzegani przez Basków negatywnie i żyją na marginesie baskijskiego społeczeństwa (do tego stopnia, że jeden z moich rozmówców - nauczyciel pracujący w szkole mieszczącej się w stolicy BWA, w dzielnicy zdominowanej przez ludność cygańską - wspominał, że niektórzy z kilkunastoletnich uczniów nigdy nie wyszli poza „swoją” dzielnicę, nie znają nawet miejskiej Starówki). Jego zdaniem przyczyną tego jest lęk i niepewność, jaką odczuwają w kontakcie z ludnością dominującą a to wywołuje często agresję. Z kolei agotak uznawani byli za "nieczystych" wyznaczano dla nich osobne przestrzenie, przypisywano im choroby, fizyczne ułomności, ale i zły charakter [Fernández Montes, 1996: 499]. 
związanymi z coraz większą różnorodnością kulturową, procesami globalizacyjnymi, migracjami. Niektórzy widzą w tych procesach szansę na zbudowanie nowego, bardziej otwartego społeczeństwa, inni $\mathrm{z}$ niepewnością patrzą w przyszłość, zastanawiając się, jak w zetknięciu ze wzbogacającą odmiennością nie zatracić własnej odrębności i snują rozważania nad tym, w jaką stronę zmierza dziś baskijska tożsamość [Martínez de Luna, 2008: 420-421; Jáuregui Bereciartu, 1999: 44-53; Pérez-Agote, 1999: 54-67].

\section{Baskowie - uprzywilejowana mniejszość?}

Znajdująca się na terenie państwa hiszpańskiego Baskijska Wspólnota Autonomiczna, potocznie utożsamiana jest z Krajem Basków, choć składają się na nią tylko trzy z siedmiu baskijskich prowincji (pozostałe to hiszpańska Nawarra oraz trzy regiony we francuskiej Baskonii, określanej przez Basków jako Iparralde ${ }^{6}$ ). Niektórzy podkreślają uprzywilejowany status regionu, korzystny system podatkowy, fakt, że posiada własny rząd czy policję. W odniesieniu do tego ostatniego aspektu warto dodać, że część Basków domaga się raczej zmniejszenia militaryzacji regionu, a język baskijski ma status urzędowego na równi z hiszpańskim (niekiedy wyłącznie w teorii, choć proces normalizacji euskary ${ }^{7}$ postępuje ${ }^{8}$ ). Tym samym baskijskie dążenia do zmiany status quo bywają uznawane za nieuzasadnione, godne potępienia i szkodliwe [Etxeberria, 2001: 84-92; Fundación Progreso y Democracia, 2014]. Z pewnością kondycja języka i kultury baskijskiej w Baskijskiej Wspólnocie Autonomicznej jest znacznie lepsza niż w pozostałych częściach Kraju Basków (według danych UNESCO euskara na terenie francuskiej Baskonii ma status języka zagrożonego), choć i tu mamy do czynienia z działaniami odbieranymi przez Basków jako atak na baskijską

6 W języku baskijskim Iparralde to 'część północna'. Baskijskie prowincje znajdujące się w Hiszpanii określane są natomiast jako Hegoalde ('część południowa').

7 Euskara - język baskijski. W tekście słowo będzie odmieniane.

8 Moi rozmówcy podkreślali, że często nawet wśród urzędników państwowych ma ona bardzo ograniczony charakter. Zdarza się, że urzędnik prosi o kontynuowanie rozmowy w języku hiszpańskim, w którym czuje się bardziej pewnie (sama również spotkałam się z taką sytuacją podczas prowadzenia wywiadów). Jeden z moich rozmówców opisując rozmowę telefoniczną, podczas której pracownik urzędu miasta zachował się w taki sposób, stwierdził, że błędem było przystanie na prowadzenie konwersacji po hiszpańsku. Uznał, że powinien poprosić o przekazanie jego sprawy baskijskojęzycznej osobie, a fakt, że tego nie zrobił wynika z silnie zakorzenionego u wielu Basków odczucia, że „mówienie w euskara to problem i przejaw braku szacunku dla rozmówcy". 
kulturę (np. zamknięcie jedynego wydawanego w całości w języku baskijskim dziennika „Egunkaria”) ${ }^{9}$.

$\mathrm{Na}$ relacje pomiędzy Baskonią i Hiszpanią wciąż cieniem kładą się wydarzenia z przeszłości, zwłaszcza okres dyktatury frankistowskiej i zamachy dokonywane przez organizację ETA. Z jednej strony przypomina się liczbę ofiar terroru ETA, z drugiej Baskowie nadal pamiętają o działalności $\mathrm{GAL}^{10}$. Nie można pominąć tu również aspektu, na który zwraca uwagę baskijski profesor, Petxo Idoyaga, a mianowicie tego, że język, czy inicjatywy promujące baskijską kulturę są kryminalizowane w myśl zasady, że „skoro ETA jest probaskijska, to wszystko co probaskijskie jest związane z ETA" [Idoyaga, 2008: 118].

Warto zauważyć, że sposób przedstawiania Basków przez hiszpańskie media czy polityków wykazuje często cechy paniki społecznej. Zjawisku temu towarzyszy niewielka wiedza na temat regionu. Baskowie bywają postrzegani w sposób stereotypowy, budzą śmiech (typ Josetxu el vasco ${ }^{11}$, bohaterowie filmu Ocho apellidos vascos ${ }^{12}$ ) lub lęk (Bask-terrorysta ${ }^{13}$ ). Sto-

9 Przywoływane są również przypadki łamania praw człowieka przez hiszpańską policję i władze sądowe czynione w imię ", walki z terroryzmem” (doniesienia znajdują się m.in. w raportach Amnesty International), [Ibarra, Zallo, 2008: 47]. O zamknięciu „Egunkarii” i prawnych konfliktach pomiędzy Baskami i Hiszpanami pisał m.in. Joaquín Navarro w książce Homenaje a Euskal Herria.

10 Na festiwalu filmowym w San Sebastian w 2014r. przedstawiony został film Lasa eta Zabala (reż. Pablo Malo), który ukazuje historię porwania i zamordowania dwóch członków ETA (przez, stanowiącą ciemną stronę hiszpańskiej walk z terroryzmem, organizację GAL), a także trudności z osądzeniem winnych. Bez wątpienia normalizacja baskijsko-hiszpańskich relacji wymaga uznania, że konflikt nie ma czarno-białego charakteru.

11 Bohater komiksu stworzony przez katalońskiego artystę Joaquima Muntañolę w latach sześćdziesiątych XX w. Postać ta, przez niektórych przyrównywana do komiksowego marynarza Popeye czy herosa Hulka, uosabiała stereotypowego Baska, tak przez strój (np. beret), jak i cechy osobowe (silny, honorowy, nieśmiały w stosunku do kobiet). Zob. m.in. http://www. lavanguardia.com/cultura/20120427/54285861909/dibujantes-vascos-homenajean-muntanola -tbo-josechu-el-vasco.html (19.03.2016), czy poświęconą tej postaci stronę na facebooku, którą założyli baskijscy rysownicy: http://www.lavanguardia.com/cultura/20120427/54285861909/ dibujantes-vascos-homenajean-muntanola-tbo-josechu-el-vasco.html (19.03.2015).

12 Reżyser Emilio Martínez Lázaro. Film ten ukazuje perypetie młodego mieszkańca Andaluzji, który zauroczony baskijską dziewczyną udaje przed jej ojcem, że jest Baskiem. Wizerunki tak Andaluzyjczyków, jak i Basków są tu silnie skontrastowane i opierają się na stereotypach dotyczących obu grup (południowy temperament i baskijska powściągliwość).

13 Joseba Zulaika zwraca uwagę na dwojaki sposób postrzegania baskijskiego bojownika - dla strony hiszpańskiej jest on bezwzględnym zabójcą, barbarzyńcą, Baskowie zaś nierzadko widzą w nim męczennika [Zulaika, 2011: 87 i dalsze]. 
sunki pomiędzy Baskami i Madrytem trafnie określił hiszpański dziennikarz Fernando Jauregi, który stwierdził, że miejsca te dzieli znacznie więcej niż $400 \mathrm{~km}$, a Baskonia jawi się jako niebezpieczne peryferie. Jednocześnie Hiszpanie słysząc euskarę identyfikują ją raczej z odległą, egzotyczną mową, niż jednym z języków Półwyspu. Jeszcze do niedawna w Słowniku Królewskiej Akademii Hiszpańskiej (RAE ${ }^{14}$ ) znaleźć można było definicję języka Basków jako „czegoś tak niejasnego, że nie sposób tego zrozumieć”

W okresie dyktatury Franco każdy przejaw kulturowej odrębności był likwidowany, niedozwolone było mówienie w euskara czy nadawanie dzieciom baskijskich imion [Egaña, 2009: 262-264]. Uczniowie mówiący po baskijsku w szkole byli karani, choć zdarzały się wśród nich jednostki, które nie znały nawet słowa po hiszpańsku. José Miguel de Barandiaran, baskijski duchowny, etnograf i archeolog, który był wybitnym badaczem kultury Basków wspominał, jak wielki lęk budziła w nim i jego kolegach szkoła i że nauka w niej polegała na uczeniu się na pamięć (bez zrozumienia, ze względu na niewielkie kompetencje w zakresie znajomości kastylijskiego) treści podawanych przez nauczyciela [Azcárate Berriochoa, 2013: 470]. Zmieniło się to po śmierci Franco i ustanowieniu dla Baskonii statutu autonomicznego. Baskijski język i kultura stały się elementem obecnym w przestrzeni publicznej i promowanym. Obecna polityka rządu baskijskiego ukierunkowana jest na działania wspierające baskijską kulturę (oraz jej upowszechnianie poza granicami). Paradoks polega na tym, że zdaniem niektórych są one niewystarczające, według innych zaś nadmierne ${ }^{16}$.

Na przestrzeni kilku baskijskich pokoleń mamy więc do czynienia $\mathrm{z}$ fundamentalnymi przeobrażeniami, związanymi ze statusem języka i kultury Basków. W odniesieniu do tak odmiennych realiów życia kilku baskijskich generacji nadzwyczaj celne wydaje się spostrzeżenie, że dla starszych pokoleń tradycja stanowiła element naturalny i przyjmowany bezrefleksyjnie, ich dzieci starały się zapomnieć o tym, co baskijskie, co stało się przedmiotem drwin i represji ${ }^{17}$, a dzisiejsi młodzi próbują powrócić do tego,

14 Real Academia Española.

15 http://lema.rae.es/drae/?val=vascuence (01.12.2014), (definicja ta była krytykowana przez Basków, obecnie występuje w formie poprawionej)

16 Takie przeciwstawne postawy (określane niekiedy jako „wewnętrzne rozbicie” i „główny problem Basków”) uwidaczniały się w moich badaniach. Dla części z moich rozmówców "baskijskie odrodzenie", jakiego stali się świadkami, ma w sobie coś sztucznego.

17 Należy zarazem pamiętać, że marginalizacja języka baskijskiego nie była w epoce Franco czymś nowym, już wcześniej deprecjonowano euskarę, uznając ją za język niewykształconych 
co minione, która to postawa niesie jednak ze sobą ryzyko folkloryzacji [Eriksen 2013: 192]. Ponadto, w wyniku represji nastąpiło przerwanie ciągłości międzypokoleniowej komunikacji, zdarzało się przecież, że dziecko, które nie znało euskary miało kłopot, aby porozumieć się z wyłącznie baskijskojęzycznymi dziadkami. Dziś Baskowie żyją w regionie, w którym tożsamość baskijska staje się przedmiotem dumy, a obecność kluczowych składników baskijskiej kultury (takich jak język) jest coraz bardziej widoczna w codzienności. Jeszcze niedawno represjonowana i dewaloryzowana kultura dziś przeżywa swój rozkwit (choć, co należy podkreślić, dotyczy do Baskijskiej Wspólnoty Autonomicznej, z francuskiej Baskonii i hiszpańskiej Nawarry dochodzą bowiem raz po raz doniesienia o utrudnieniach, jakie stawiane są przed tymi, którzy działają na rzecz baskijskiego języka i kultury ${ }^{18}$ ).

Jednocześnie współczesna Baskonia staje wobec nowych wyzwań, teraz związanych już nie tylko z położeniem pomiędzy dwiema silnymi kultura$\mathrm{mi}^{19}$ czy wewnętrznymi animozjami (np. autonomia Nawarry), ale też pojawieniem się w regionie nowej grupy - imigrantów spoza Hiszpanii i Francji.

\section{Baskowie wobec obcych}

Według baskijskich wierzeń nad brzegami rzek i strumieni można spotkać istotę nazywaną w języku baskijskim lamia. Miała ona wygląd pięknej kobiety, jednak posiadała stopy przypominające ptasie. Zdarzało się, że zakochiwał się w niej jakiś mężczyzna, jednak nigdy nie była to miłość szczęśliwa. Relacje tego typu odczytywać można jako jasne ostrzeżenie przed związkiem z kimś spoza naszej grupy, z obcym, postrzeganym często jak „nie w pełni człowiek” [Arana Williams, 1989: 115 i dalsze]. Dystans w stosunku do obcych znalazł odzwierciedlenie również $\mathrm{w}$ innych baskijskich legendach, których bohaterami były często grupy żyjące w separacji. Zgod-

mieszkańców wsi. W jego niską wartość uwierzyła też część Basków. Miguel de Unamuno nawoływał do porzucenia euskary („niczym zbyt ciasnego ubrania”), [Zuazo, 2010 : 32-33].

Zob.m.in.http://www.teinteresa.es/noticias/ministro-Interior-medidas-terroristas-profesores_0_1049895754.html (04.03.2016), http://www.euskalkultura.com/espanol/noticias/jean-claude-iriart-director-de-eep-la-situacion-del-euskera-en-iparralde-es-muy-grave-partimos-de -esa-base (04.03.2016).

19 Zdaniem baskijskich językoznawców prawdziwą zagadką dotyczącą języka baskijskiego nie jest jego pochodzenie, lecz fakt, że przetrwał pomimo wieków represji, marginalizacji [Zuazo, 2010: 15]. 
nie $\mathrm{z}$ jedną $\mathrm{z}$ hipotez mityczne olbrzymy gentilak to $\mathrm{w}$ istocie pogańskie społeczności, które mieszkały w górach, i którym z biegiem czasu przypisywać zaczęto nadnaturalną siłę i niezwykłe umiejętności. Stopniowo też zaczęły one budzić strach [Arriaga 2000: 13-14]. W podobny sposób widziano jednak niekiedy nawet mieszkańców sąsiednich wsi, a nawet dzielnic (potwierdzali to moi rozmówcy). Obcym był też ten, kto pochodził z miasta, czyli kaletarra. Warto podkreślić, że „miastowy” traktowany był z pewną pogardą, jako ten „kto nie zna prawdziwej pracy”, którego moralność jest wątpliwa. Małżeństwo $\mathrm{z}$ nim zawarte postrzegane było $\mathrm{w}$ kategoriach mezaliansu [Berriochoa Azcárate, 2013: 318, 354-355]. Paddy Woodworth, irlandzki dziennikarz, pisał, że podział „wieś-miasto” to „najgłębsza granica w Kraju Basków" [2007: 6], a Ksawery Pruszyński [1997: 353-354] zauważał jej etniczny charakter (baskijska wieś kontra zhispanizowane miasto). Odrębność tych kulturowych przestrzeni do dziś wydaje się wyraźna:

„W dzieciństwie wyjazd do San Sebastian był dla mnie jak wyjazd do innego państwa. Myślałem, że to już nie jest Kraj Basków, bo tam nie mówiło się po baskijsku na ulicy" (Bask, 39 lat).

W tradycyjnym systemie wartości rola gospodarza, właściciela domu była największym zaszczytem. Taki sposób postrzegania życiowego sukcesu uległ zmianie, gdy okazało się, że rodzeństwo, które opuściło dom miało szansę (i zdobyło) lepsze wykształcenie, pracę, czy majątek. Znaczenie tradycyjnego gospodarstwa we współczesnej kulturze baskijskiej to bez wątpienia interesujące zagadnienie (ideologiczne znaczenie baserrii).

Podstawowy podział na „swoich” i „obcych” wyznaczał język. Baskijski endoetnomim euskaldunak oznaczał wszak tych, którzy mówią w języku baskijskim (euskara). Pozostali określani byli jako erdaldunak - 'posiadający inną mowę’. Współcześnie definiowanie Baska nie jest tak jednoznaczne. Obecnie znaczenie euskary wykracza poza jej praktyczną przydatność (na co dzień, zwłaszcza w większych miastach wystarczy znajomość hiszpańskiego, jednak np. w sferze zawodowej certyfikat znajomości baskijskiego ma duże znaczenie), ma natomiast istotny wymiar symboliczny (o czym przekonywałam się wielokrotnie podczas badań terenowych w regionie baskijskim). Jednocześnie pomimo częstego podkreślania znaczenia języka dostrzega się fakt, że Baskonię zamieszkują osoby, które urodziły się tu i identyfikują się z miejscową kulturą, jednak z różnych 
powodów (np. w wyniku represji w okresie dyktatury frankistowskiej ${ }^{20}$ ) nie mówią w euskara. Sytuację komplikuje fakt pojawiania się baskijskojęzycznych imigrantów ${ }^{21}$, czy to, że ich dzieci będące nadal „widoczną mniejszością" (ze względu np. na kolor skóry czy noszenie muzułmańskiej zasłony) płynnie posługują się językiem baskijskim. Zdarza się, że te ostatnie, pomimo posługiwania się euskarą i postrzegania Kraju Basków jako „ojczyzny” są traktowane z dystansem, nie do końca uważane za „Basków”. Barierą pozostaje tu element podkreślający ich odmienność, np. chusta, która przez znaczną część społeczeństwa oceniana jest pejoratywnie (np. jako symbol opresji wobec kobiet).

Świadomość własnej odrębności konstruuje się w zetknięciu $\mathrm{z}$ innością, a charakter granicy pomiędzy ,jednym z nas” i „obcym” wskazuje na warunki i możliwości włączania do grupy. W tym kontekście Ignacio Irazuzta i María Martínez wyróżnili trzy etapy związane z definiowaniem baskijskiej tożsamości zbiorowej. Pierwszy z nich związany był z dziewiętnastowiecznym naciskiem na aspekt rasy, który w sposób oczywisty był nieprzekraczalny dla osoby pochodzącej z zewnątrz (co więcej Sabino Arana podkreślał konieczność zachowania „czystości krwi” i zagrożenie, jakim są przybysze dla baskijskiej kultury i moralności). Późniejsi ideolodzy (lata sześćdziesiąte XX w.) odeszli od tak wąskiego definiowania Baska. W drugim etapie desygnatem baskijskości był bowiem język - euskara. To fakt jego znajomości, możliwy do osiągnięcia także przez ludność napływową, miał charakter decydujący (choć istniała w tym względzie pewna hierarchia pomiędzy tymi, dla których baskijski był językiem ojczystym i dla tych, którzy nauczyli się go później22). Faza ostatnia (od lat osiemdziesiątych XX w.) związana jest $\mathrm{z}$ uzyskaniem statusu regionu autonomicznego i postrzeganiem bycia Baskiem w związ$\mathrm{ku} \mathrm{z}$ faktem zamieszkiwania regionu (instytucjonalizacja tożsamości), [Irazuzta, Martínez, 2014: 15-22]. Te trzy elementy wyznaczają główne sposoby definiowania baskijskiej tożsamości zbiorowej, choć należy pamiętać, że dys-

20 Wielu rodziców chciało, by ich dzieci uniknęły kar i trudności. Koldo Zuazo, baskijski dialektolog, przytacza też relację kobiety, której jedna z wnuczek mówi tylko po hiszpańsku (w przeciwieństwie do całej baskijskojęzycznej rodziny). Przyczyną był fakt, że nauczycielka poinformowała rodziców, iż kłopoty w szkole dziecka wynikają z tego, że w domu mówi ono po baskijsku i zaleciła komunikowanie się wyłącznie w języku hiszpańskim [Zuazo, 2010: 30].

21 Nie bez znaczenia jest to, że dziś języka baskijskiego można dziś uczyć się na lektoratach działających na całym świecie (rozpowszechnianie to jeden z priorytetów baskijskiej polityki językowej), w tym w Polsce.

22 Stąd podział na euskaldun zaharrak, dla których euskara jest językiem ojczystym i euskaldun berriak, którzy nabyli ją jako drugi, bądź kolejny język. 
kusja na jej temat (tocząca się, jak zauważają sami Baskowie, od ponad wieku) nie jest zakończona i rozstrzygnięta. Element językowy chociażby nadal odgrywa znaczącą rolę (zwłaszcza wśród euskaldun zaharrak), podkreśla się ponadto aspekt woli, utożsamiania się z baskijską kulturą (tożsamość $\mathrm{z}$ wyboru?). Istotnym elementem jest tu również fakt administracyjnego rozbicia i silna tożsamość Nawarczyków.

\section{Od emigracji do imigracji}

Kultura baskijska opisywana jest często jako niezwykle hermetyczna. W tym kontekście analizuje się choćby fenomen kuadrilla - grupy przyjaciół (hiszp. cuadrilla), o której również dziś mawia się, że „nie można do niej wejść, trzeba się w niej urodzić"23. Znacząca jest także koncepcja domu w tradycji baskijskiej, domu, który można wręcz uznać za słowo-klucz dla kultury Basków ${ }^{24}$. Postrzegany był on jako wspólnota żywych i zmarłych, był to nie tylko budynek, ale i ziemia czy zwierzęta, a cechowała go znaczna autonomia, w tym językowa - zdarzało się, że sąsiadujące ze sobą domy charakteryzowało inne słownictwo. Baskijskie gospodarstwo (baserria) było w istocie "firmą w miniaturze" [Douglass, Bilbao 1986: 490]. Niejedna $\mathrm{z}$ anegdot przywoływanych przez Basków odnosi się do delegacji mieszkańców, która odwiedza nowego osiedleńca informując go, że buduje dom zbyt blisko swojego sąsiada (co oznacza odległość kilku kilometrów). $\mathrm{Na}$ swoistą izolację przed tym, co obce wskazywać ma już sama etymologia słowa dom (etxe), która bywa łączona ze słowem „zamknięty”25. Zamknięcie to zdaje się paradoksalne, jeśli zwrócimy uwagę na historyczną mobilność Basków, na fakt, że emigracja stanowiła zasadniczy rys ich kultury. Baskami byli słynni konkwistadorzy, wielorybnicy, czy piraci, ale też polityczni uciekinierzy. Emigracji sprzyjał system dziedziczenia - dom przejmowało tylko jedno, spośród licznych zwykle, dzieci. Dlatego dla wielu młodych Basków wizja wyjazdu była jak najbardziej naturalna, wręcz tradycyjna (dotyczącą jednak, co należy podkreślić, przede wszystkim mężczyzn), [Douglass, Bilbao: 174-177]. O powszechności takiej życiowej drogi świadczy choćby popularne powiedzenie, zgodnie z którym jedną z cech prawdziwego Baska jest posiadanie krewnych w Ameryce [Kurlansky,

23 Wielu moich rozmówców, imigrantów, podkreślało, że bardzo trudno zaprzyjaźnić się z Baskami.

24 Na temat słów-kluczy zob. [Wierzbicka, 2007: 41 i dalsze].

25 http://projetbabel.org/basque/diccionario.php?q=etxe (04.03.2016). 
2000: 103], czy sława, jaką cieszyli się w Nowym Świecie baskijscy pasterze (baskijskie pochodzenie bywało w tej branży najlepszą rekomendacją). Emigracja (której głównym celem były obie Ameryki) wywarła też wpływ na kulturę baskijską na Starym Kontynencie (choćby w sferze gastronomii - kukurydza i fasola stały się podstawą tradycyjnej kuchni Basków), [Douglass, Bilbao: 105, 497]. Równie interesująca była pozycja emigranta powracającego z Ameryki, z racji zdobytego majątku chętnie widzianego jako kandydata do małżeństwa. Jednocześnie warto podkreślić, że również na emigracji zauważalne było zjawisko koncentracji baskijskiej mniejszości ${ }^{26}$ czy endogamii (popularne były małżeństwa oparte na zasadzie wymiany sióstr), [Douglass, Bilbao: 425]. Dochodziło także do zawierania małżeństw przez wykluczonych z dziedziczenia gospodarstwa (otrzymywali oni jednak pewien posag), którzy wspólnie emigrowali (choć zdarzały się też przypadki, że żona nie chciała wyjeżdżać wraz z mężem i zostawała w Baskonii ze swoją rodziną), [Arrizabalaga 2008: 120] ${ }^{27}$.

Współcześnie Kraj Basków staje się w coraz większym stopniu celem dla migrantów (i to nie tylko jako miejsce tranzytowe). Zjawisko to jest o tyle nowe, że wcześniejsze fale imigracyjne miały charakter wewnętrzny i były związane z napływem ludności z innych regionów hiszpańskich. Warto podkreślić, że postać imigranta odegrała istotną rolę zarówno $\mathrm{w}$ procesie powstawania baskijskiego nacjonalizmu, jak i w odniesieniu do jego charakteru, a być może i w związku z kierunkiem, w jakim zmierza współcześnie. Genezy baskijskiego nacjonalizmu upatruje się w utracie lokalnych przywilejów i praw (hiszp. Fueros, bask. Foroak), które przysługiwały baskijskim prowincjom oraz związanym $\mathrm{z}$ tą sytuacją napływem imigrantów z innych regionów Hiszpanii (XIX w.). Populacja niektórych miejscowości zwiększyła się nawet dwukrotnie, a obawa przed „zalaniem” przez obcych i zagrożeniem kultury baskijskiej stały się ważnym elementem w nacjonalistycznej ideologii. Imigrant (Hiszpan) i podział „my-oni” (Baskowie-Hiszpanie) miały więc w tym kontekście kluczowy charakter.

26 Do dziś liczne są w obu Amerykach centra kultury baskijskiej - Euskal Etxeak (Domy baskijskie), skupiające wokół siebie baskijską diasporę i promujące kulturę Basków.

27

O baskijskich relacjach miłosnych (a raczej ich braku) nadal krąży wiele żartów. Podkreśla się pragmatyczny stosunek do zawierania związków i nadrzędny ich cel - prokreację. Nadrzędność dobra rodziny nad szczęściem jednostki leżała u podstaw wydawania za mąż córki za kandydata o dobrym statusie materialnym. Przed małżeństwem z miłości ostrzega nawet baskijskie przysłowie - Ezkontza amodiozko bizitza dolorezko (tłum. „Małżeństwo z miłości to życie w boleści") 
Sabino Arana, główny ideolog baskijskiego nacjonalizmu, nazywał go maketo uznawał za ucieleśnienie wszelkich wad (i przeciwieństwo Baska), [Stallaert, 1998; 82-84]. Również ci hiszpańscy imigranci, którzy przybyli w latach sześdziesiątych, siedemdziesiątych XX w. byli traktowani z dystansem, wyższością, niekiedy nawet $\mathrm{z}$ wrogością, co wielu $\mathrm{z}$ nich nadal wspomina. Niektórzy Baskowie do dziś krytycznie wypowiadają się na temat tych hiszpańskich imigrantów, którzy inaczej wyglądali i nigdy nie nauczyli się euskary. Inni jednak przyznają, że nie zawsze byli oni dobrze traktowani przez rodowitych mieszkańców regionu. Jednocześnie zdarzało się, że drugie pokolenie imigrantów w znacznej mierze asymilowało się, pojawiały się wśród nich nawet jednostki aktywnie działające na rzecz baskijskiej suwerenności (również w wymiarze radykalnym - jako członkowie ETA) ${ }^{28}$. W odniesieniu do imigrantów stosowano szereg określeń o charakterze pejoratywnym, podkreślających ich inność (obyczaje, strój), brak znajomości języka baskijskiego, ale tez odnoszących się do kwestii politycznych. W niektórych miejscowościach baskijskich jako „faszystowskie” określano dzielnice zamieszkane przez imigrantów z Hiszpanii. Podczas badan często spotykałam się z relacjami mówiącymi o doświadczonej, ze strony ludności miejscowej, niechęci:

„Baskowie mówili na mnie fatxi - faszysta” (Hiszpan, 48 lat).

„Dzieci w szkole wołały na nas coreanos. Zmieniło się to dopiero, gdy dowiedziały się, że mój ojciec pochodzi z Nawarry i mamy jedno baskijskie nazwisko" (Hiszpanka, 67 lat).

Hiszpania mniej więcej od lat osiemdziesiątych XX w. staje się krajem imigracyjnym (mimo znacznych emigracyjnych tradycji), [Reher, Requena, 2009: 8-11]. W przypadku Kraju Basków zjawisko to było nieco późniejsze (lata dziewięćdziesiąte) i bardziej ograniczone, jeśli chodzi o procent ludności imigracyjnej (choć przyrost był zauważalny). Autorzy raportu na temat imigracji w BWA z 2014 r. wyróżniają trzy główne grupy imigranckie w regionie: latynoską (najliczniejszą), pochodzącą z Unii Europejskiej oraz z Magrebu [Ikuspegi, 2014: 6]. Imigrację w Kraju Basków cechuje znaczna różnorodność społeczna (nie tylko w wymiarze etnicznym). Imigranci to zarówno specjaliści, w tym osoby o wysokim poziomie kompe-

28 Ci hiszpańscy imigranci niekiedy sprzeciwiali się integracji swoich dzieci, zakazywali im nauki baskijskiego, choć częstsze były raczej sytuacje przeciwne, całkowita asymilacja. Jeden z moich rozmówców opowiadał mi o braciach, mieszkających w jego miejscowości, których rodzice przyjechali z południa Hiszpanii. Dziś ci młodzi chłopcy rozmawiają ze sobą tylko w euskara (co bardzo denerwuje ich dziadka, którego odwiedzają w miejscu pochodzenia rodziny), identyfikują się z baskijskim ruchem narodowym (patriotycznym). 
tencji kulturowo-językowej (znające nie tylko język i kulturę hiszpańską, ale i baskijską), jak i analfabeci czy nieletni migranci bez opieki. Stąd o ile wcześniejsze fale imigracyjne miały charakter wewnętrzny, obejmowały przybyszy z innych hiszpańskich prowincji, o tyle teraz mamy do czynienia $z$ prawdziwą kulturową mozaiką. I choć celem większości imigrantów są duże miasta to jednak niektórzy, również ze względów zawodowych, trafiają do małych miejscowości ${ }^{29}$ (a charakter integracji zależy od miejsca osiedlenia się - bez wątpienia inny jest w małych, baskijskich miejscowościach, w których językiem codziennym jest dialekt euskary).

Niejednolity jest też sposób postrzegania tych poszczególnych etniczności ${ }^{30}$. Imigranci pochodzący $z$ Magrebu są tymi, którzy w największym stopniu spotykają się z niechęcią i odrzuceniem [Ikuspegi, 2014: 43-45] [Cebolla, Requena 2009: 283]. Zauważalne jest zarazem traktowanie grupy z tego samego obszaru jako homogenicznej. Stąd tak częste nazywanie wszystkich kobiet pochodzących z Ameryki Łacińskiej jako sudamericanas (nawet, jeśli, jak z oburzeniem, powiedziała jedna $\mathrm{z}$ moich rozmówczyń: „Ja pochodzę z Ameryki Środkowej”). W podobnie ujednolicony sposób określa się osoby pochodzące z Maroka (nie wyróżniając na przykład Berberów ${ }^{31}$ ). Takie ujednolicanie różnorodnych grup budzi wśród ich przedstawicieli sprzeciw [Ikuspegi, 2014: 41-43].

Interesujący jest sposób postrzegania imigrantów z Europy Środkowej i Wschodniej, którzy w ostatnich latach w znaczący sposób zwiększyli swoją obecność na terytorium Hiszpanii [Pajares 2007: 74]. Z jednej strony uważa się ich za cywilizacyjnie słabiej rozwiniętych („Wy nie jesteście taką samą Europą jak Niemcy czy Francuzi”), utożsamia z żebractwem i przestępczością - trafne wydaje się to spostrzeżenie, że „słowo Rumun stało się w całej Europie rodzajem obelgi” [Naïr 2010: 212]. Z drugiej obecny jest stereotyp „słowiańskiej Barbie”, idealnej kandydatki na żonę (istnieją nawet agencje wyspecjalizowane w kojarzeniu par z obszarów Europy Środkowej i Wschodniej oraz Hiszpanii), ze względu na urodę i fakt, że dom i rodzina stanowić mają dla niej priorytet (przeciwieństwem mają być wyemancypowane kobiety miejscowe), [Kunz 2002: 172].

29 Przykładem mogą być rybacy pochodzący z Senegalu, których coraz częściej spotkać można w baskijskich portach.

30 Niekiedy zwraca się uwagę na specyfikę samego zastosowania określenia "imigrant” i fakt, że rzadko wykorzystuje się to słowo w stosunku do przybyszy z "Pierwszego świata" [Marín Escudero 2014: 84; Reher, Requena, 2009: 13-14] .

31 „My jesteśmy takimi Baskami Maroka” - powiedział mi jeden z nich (Berber, 19 lat). 
Warto zwrócić uwagę na jeszcze jeden aspekt. Jest on związany ze sposobem, w jaki sami imigranci postrzegają innych imigrantów. Zauważalne są tu bowiem postawy dyskryminacyjne, poczucie wyższości, rasizm. Kategoria bycia „dobrym” czy „lepszym” imigrantem nie ma zatem tylko charakteru zewnętrznego (związanego z perspektywą społeczeństwa przyjmującego):

„Słyszałem o chłopaku z Ameryki Południowej, który szukał współlokatora. Podkreślał jednak stanowczo, że nie może to być żaden Marokańczyk, czy Algierczyk, chciał mieszkać wyłącznie z Baskami. Nie pomyślał jednak, że Bask może nie chcieć właśnie jego za współlokatora..." (Bask, 42 lata).

\section{Integracja „po baskijsku” - wyzwania}

We wcześniejszej części tego artykułu zarysowana została złożona sytuacja regionu baskijskiego, wewnętrzne podziały i granice, bolesna przeszłość, trudne relacje z centralną władzą, dążenia separatystyczne (dziś zauważalna jest tendencja do umiędzynarodawiania „baskijskiego problemu"32). Imigranci, którzy pojawiają się w Kraju Basków, trafiają więc w sam środek tego tygla. Jednocześnie wielu z nich nie zdawało sobie wcześniej sprawy z kulturowej odrębności tej hiszpańskiej prowincji. Stąd niektórzy imigranci mówią o związanej z tym faktem trudności w adaptacji („ZZ którą kulturą powinienem się integrować?”). Z drugiej strony dla części z nich panująca w regionie dwujęzyczność i dwukulturowość nie stanowi większego problemu - tak jest w przypadku tych grup, które pochodzą z krajów o znacznej wewnętrznej różnorodności i dla których posługiwanie się na co dzień kilkoma różnymi językami jest czymś naturalnym:

„Afrykanie, którzy do nas przyjeżdżają mówią u siebie w, dajmy na to, trzech językach, tu po prostu uczą się kolejnych dwóch” (Bask, 39 lat).

Przykład ten jest szczególnie interesujący, zwraca bowiem naszą uwagę na możliwość innego sposobu przeżywania migracji, podejścia do własnej tożsamości, czy charakteru integracji. Przywykliśmy do traktowania fenomenu migracji jako kryzysu a jego uczestników jako ofiar skazanych na tęsknotę za opuszczoną ojczyzną, którzy nigdy do końca nie zintegrują się z „nowym domem" [Lindner, 2000: 10-11]. Bez wątpienia dla wielu migrujących wyjazd stanowił konieczność, a oni sami czują się rozdarci i pozbawieni przynależ-

32 Między innymi przez organizowanie spotkań z zagranicznymi politykami i negocjatorami, czy współpracę z innymi mniejszościami. 
ności do którejkolwiek z kultur (dotyczy to często drugiego pokolenia). Wielu ma za sobą traumatyczne przeżycia. Część imigrantów obawia się tego, że ich dzieci oddalą się od kultury przodków, przestaną mówić w języku rodziców, staną się „obce” [Etxeberria Mauleon, Ruiz Vieytez, Vicente Torrado, 2007: 150 i dalsze]. Jednak z drugiej strony protagonistami dzisiejszych zjawisk migracyjnych są nie tylko emigranci i imigranci, lecz także transmigranci, obecni w różnych kulturowych przestrzeniach i ze względną łatwością zmieniający kulturowe kody (niektórzy badacze nie uznają za zasadne wprowadzanie kategorii transmigranta), [Kindler 2008: 51-56]. A także osoby, dla których prawdziwą ojczyzną stała się ta „wybrana”.

Wydaje się, że wyzwanie, przed jakim stoją dziś Baskowie, nie jest związane już „tylko” z tym, w jaki sposób wspierać i chronić baskijską kulturę przed hiszpańskimi i francuskimi wpływami, procesami globalizacji, czy atrakcyjnością języka angielskiego wypierającego niekiedy euskarę. Dziś konieczne staje się znalezienie drogi pozwalającej na włączenie do baskijskiego społeczeństwa imigrantów. Z jednej strony zauważalne są liczne inicjatywy na rzecz obywatelskiej równości i wyrazy poparcia dla różnorodności (warta wspomnienia była choćby aktywność mieszkańców baskijskiej stolicy zjednoczonych wokół ruchu Gora Gasteiz sprzeciwiających się mowie nienawiści obecnej i ksenofobicznej postawie miejskich władz), z drugiej wydaje się, że największym wyzwaniem polityki integracji jest stworzenie społeczeństwa międzykulturowego. Skonstruowanie Baskonii nie tyle różnorodnej kulturowo, ile złożonej z grup wchodzących we wzajemne relacje (a także przemyślenia na nowo tego, czym jest i ma być baskijska tożsamość), pamiętając, że tolerancja na najbardziej podstawowym poziomie odnosi się wyłącznie do braku agresji wobec innych, do ich „znoszenia”. Wciąż zauważalne są przejawy dyskryminacji (uwidaczniającej się często w codziennym traktowaniu „innych”), [Manzanos Bilbao 1999: 137 i dalsze], choć podejmuje się wiele inicjatyw mających na celu oswojenie leku przed odmiennością czy weryfikacji popularnych sądów (ulotki, warsztaty, wykłady w szkołach, literatura, i inne ${ }^{33}$ ). Znaczącym problemem wydaje się elitaryzacja edukacji w regionie. W baskijskim systemie

33 Jedną z bardziej interesujących inicjatyw była ta mająca miejsce w Bilbao, której miejscem stały się zakłady fryzjerskie. Organizatorzy wyszli z założenia, że wizyta u fryzjera, związana z elementem bliskiego kontaktu, fizycznego i duchowego (konwersacje) jest świetnym sposobem na przełamanie stereotypów. Dlatego też przygotowano akcję, w ramach której zakupiony bon upoważniał do wizyty w trzech, biorących udział w projekcie, zakładach fryzjerskich (europejskich, afrykańskich, latynoamerykańskich), http://www.ikuspegi.eus/eus/prensa/entrada_ prensa.php?id=78258 (05.03.2016). 
edukacyjnym mamy do czynienia z trzema głównymi modelami (A, B, D) wyróżnionymi ze względu na język wykładowy (A - hiszpański, euskara występuje jako jeden $\mathrm{z}$ przedmiotów, B - połowa przedmiotów nauczana w języku hiszpańskim, połowa w baskijskim, D - euskara). Dzieci imigrantów trafiają głównie do szkół publicznych prowadzących naukę w języku hiszpańskim, autochtoni wybierają zwykle szkoły z euskara jako wykładowym, często są to placówki niepubliczne. Bywa, że baskijscy rodzice przenoszą swoje dzieci do szkół prywatnych, obawiając się obniżenia poziomu wynikającego z obecności imigrantów, ich agresji, negatywnego wpływu rówieśników pochodzących $\mathrm{z}$ innych krajów. Taka sytuacja (określana przez niektórych wręcz jako gettoizacja) nie sprzyja budowaniu społeczeństwa międzykulturowego [Martínez, 2014: 80-86].

Ponadto zdarza się, że nawet walce na rzecz poprawy sytuacji imigrantów towarzyszą ukrywane (bądź nie do końca uświadamiane) postawy dyskryminujące, czy wykluczające. Mam tu na myśli działaczy, którzy nie widzą możliwości przyjaźni z imigrantami, czy rodziców przenoszących swoje dzieci do prywatnych szkół, aby „uchronić” je przed negatywnym wpływem „obcych”. Jedna z moich rozmówczyń opowiadała o przyjaciółkach zaangażowanych w nauczanie kobiet imigrantek języka hiszpańskiego, które jednocześnie wypowiadały się o swoich uczennicach z poczuciem wyższości oscylującym pomiędzy litością a pogardą. Z drugiej strony podkreślić należy aktywność baskijskich organizacji i ruchów społecznych działających na rzecz równości i wyróżniających się na tle Hiszpanii. W przeszłości imigracja postrzegana była przez wielu Basków jako zagrożenie. Sabino Arana pisał, że należy chronić rasę i język przed obcymi, José Luis Alvarez Enparantza podkreślał, że imigranci są zagrożeniem dla narodu, który nie ma własnego państwa [Stallaert, 1998: 82-84; Alvarez Enparantza, 1997: 230; Totoriagüena, 2004: 36-37]. Dziś jednak widać liczne inicjatywy podejmowane na rzecz wielokulturowości i integracji (co nie oznacza braku trudności z akceptacją tej wielkiej zmiany), a Baskowie bardzo pozytywnie reagują na wysiłki imigrantów związane z nauką miejscowego języka.

Za jeden $\mathrm{z}$ wyznaczników integracji uważa się małżeństwa mieszane. Związków takich w Baskonii przybywa ${ }^{34}$ (choć nie w przypadku każdej narodowości), jednak niekiedy rodzina i przyjaciele tak jednej, jak i drugiej strony podchodzą do takiej relacji nieufnie, a w przypadku rozstania lub zdrady

34 http://www.eustat.eus/elementos/ele0002700/ti_la-mitad-de-los-extranjeros-de-la-ca-de-euskadi-conviven-con-personas-de-nacionalidad-espanola/not0002718_c.html\#axzz422YBdrWO (05.03.2016). 
chętnie odwołują się do etniczności ${ }^{35}$. Taka postawa nie jest jednak związana wyłącznie z kontekstem baskijskim i wskazuje raczej na w pewien sposób uniwersalne, silne zakorzenienie obawy przed obcym [Czykwin 2008: 53-70]. Spotykałam się również z deklaracjami osób mówiących jednoznacznie, że kandydatem do małżeństwa może być tylko inny Bask lub Baskijka (do takiego wyboru nakłaniają też niektórzy rodzice lub dziadkowie):

„To byłoby dla mnie trudne, gdybym w domu musiał posługiwać się językiem hiszpańskim (...) Wszyscy moi przyjaciele mają dziewczyny Baskijki, to musi coś znaczyć" (Bask, 38 lat).

„Moja narzeczona wiedziała, że musi nauczyć się baskijskiego. Nie mógłbym z żoną rozmawiać po hiszpańsku” (Bask, 60 lat).

„Moja babcia ciągle mi powtarza: Ale dziewczynę znajdź baskijską!” (Bask, 25 lat).

Są osoby (tak imigranci jak i Baskowie) dla których język ojczysty nabiera szczególnego znaczenia w momencie pojawienia się dzieci ${ }^{36}$.

Jednocześnie należy podkreślić, że wielu imigrantów aktywnie włącza się w proces wspierania i tworzenia baskijskiej kultury. Symboliczne wydają się tu sytuacje (zaobserwowane przeze mnie podczas badań), gdy nauczycielem euskary $\mathrm{w}$ grupie, w której uczniami są dorośli Baskowie, jest cudzoziemiec, gdy kilkuletnie córki algierskiej imigrantki, śpiewają w euskara (której ich matka nie zna), czy gdy kobiety pochodzące z Pakistanu, które zamieszkały w małym baskijskim miasteczku opowiadają o sobie w euskara (nie znają natomiast hiszpańskiego). Jedna z moich rozmówczyń będąca świadkiem tego, jak po zakończonym egzaminie z języka baskijskiego tylko imigranci kontynuowali rozmowę w euskara, miejscowi zaś przeszli na hiszpański, stwierdziła, że „Jeśli euskara przetrwa to dzięki imigrantom”. Wniosek na pewno nie powinien być tak jednoznaczny, większość imigrantów to wszak osoby pochodzące z krajów latynoskich, które nie mają dużej motywacji (ale i możliwości ${ }^{37}$ ) do nauki baskijskiego, wart jest jednak uwagi.

35 Jednocześnie jeden z moich rozmówców, którego zięć jest cudzoziemcem przyznał, że teraz trudno mu jest widzieć w przedstawicielach tej grupy narodowej imigrantów.

$36 \mathrm{~W}$ przypadku dzieci ze związków mieszanych zwykle dominujący wpływ zaczyna wywierać kultura i język kraju pobytu, jednak jednej z poznanych przeze mnie par zależało na wychowaniu dziecka w równowadze pomiędzy dwoma kulturami, czemu służyć miały naprzemienne, jednakowe w swej długości, pobyty w ojczyźnie każdego z rodziców.

37 Sami Baskowie przyznają, że rozumieją tych, którzy po kilkunastu godzinach kiepsko opłacanej pracy nie mają chęci do nauki języka. Wydaje się jednocześnie, że główny wysiłek związany z włączaniem imigrantów do społeczeństwa baskijskiego położony jest na ich dzieci. To one dzięki edukacji (większość szkół w regionie to te z modelem D, czyli baskijskojęzyczne) 


\section{Zarautz jako symbol}

Zarautz to niewielkie miasteczko położone na baskijskim wybrzeżu. Pomimo tego, że w sezonie letnim jest celem turystycznej ekspansji (populacja zwiększa się nawet kilkukrotnie, ponieważ niektórzy Baskowie posiadają tu wakacyjne mieszkania) zachowało silną baskijską tożsamość. Uwidacznia się to przede wszystkim w sferze językowej, baskijski pozostaje tu językiem obecnym w codzienności a dla najmłodszych jego użytkowników mową ojczystą i jedyną (hiszpański poznają w dalszej kolejności, za sprawą telewizji, czy szkoły). Miejscowość ta przyciąga też imigrantów. W 2014 r. powstał film ukazujący losy kilku z nich, będących jednocześnie przedstawicielami różnorodnych grup baskijskich imigrantów ${ }^{38}$. Swoją historię przedstawia tu choćby imigrant wewnętrzny, pochodzący z innego hiszpańskiego regionu, który tu znalazł miłość i założył rodzinę. Jedną z bohaterek tego dokumentu jest też kobieta z Ameryki Południowej, która zajmuje się domem miejscowej rodziny. Przejmująca relacja tej matki, zmuszonej do pozostawienia $\mathrm{w}$ ojczystym kraju trójki dzieci, z których najmłodsze, jak ona sama przyznaje z płaczem, „Nie wie co to uścisk mamy, nie wie co to znaczy mieć mamę obok siebie" wpisuje się w tak podobne (i podobnie dramatyczne) historie wielu innych imigrantek z tego obszaru, które zdominowały w Hiszpanii sektor opieki (będące zarazem ofiarami licznych nadużyćc ${ }^{39}$ ). I które postrzegane są z jednej strony jako „czułe” i „bliskie kulturowo”, z drugiej krytykowane jako leniwe i nieuczciwe. W reportażu pojawia się też Afrykanin, który z narażeniem życia dotarł do hiszpańskich brzegów, widząc śmierć niektórych swoich współtowarzyszy. Dziś zajmuje się obwoźną sprzedażą i choć podkreśla, że miejscowi dobrze go traktują, to jednak i dla niego życie z dala od bliskich jest tym, co najtrudniejsze w emigracji.

Dokument ten jest istotny nie tylko jako przykład lokalnego doświadczenia, ale i ze względu na to, że to imigrantom oddaje się tu głos ${ }^{40}$. W dysku-

stosunkowo szybko uczą się języka i tradycji baskijskich (podczas badań dostrzegałam większe kompetencje kulturowe dzieci, znających np. baskijskie postacie mitologiczne).

38 Destokian, reż. Laida Aranburu, Usua Garin, Ekhiñe Muguruza, prod. Zarauzko Udala.

39 http://www.eldiario.es/norte/euskadi/Empleada-emigrante-expuesta-sexual-laboral_0_344015694.html, (12.01.2015).

40 Podobnym przykładem umożliwienia zabrania głosu w dyskusji na temat imigracji stał się projekt stowarzyszenia Bidez Bide skierowany do nieletnich imigrantów. Jego efektem były dwie płyty CD z utworami muzycznymi, których treścią były historie i refleksje młodych migrantów. http://rapeandomigraciones.tumblr.com/ (14.11.2015). 
sjach na temat imigracji czy integracji często przyjmuje się wyłącznie perspektywę społeczeństwa przyjmującego, nawet wypowiadając się w obronie napływającej ludności mówiącymi pozostają nadal przedstawiciele autochtonów. Nie ulega też wątpliwości, że jednym z wyzwań polityki integracyjnej jest zmierzenie się z traumatycznymi losami tych, którzy przybyli. Pracownica jednej z baskijskich szkół opowiadała mi o chłopcu, który był świadkiem zabójstwa swojego ojca i, ledwo uchodząc z życiem, dotarł wraz z matką do Hiszpanii na jednej z tych przepełnionych, kruchych łodzi, które znamy z medialnych obrazów. Integracja ukierunkowana na takich imigrantów (czy nieletnich imigrantów bez opieki, którzy zresztą w momencie osiągnięcia pełnoletności nie mogą dłużej liczyć na instytucjonalną pomoc, stając się niekiedy częścią „społeczeństwa cieni”, imigrantów o nieuregulowanej sytuacji administracyjnej) musi mieć charakter szczególny.

Dziś Zarautz wydaje się także miejscem symbolicznym. W 2014 r., w efekcie potężnych sztormów, na plaży ukazały się szczątki wraku niemieckiej łodzi, która rozbić się tu miała wiele lat wcześniej ${ }^{41}$. Informacja o niej przyciągnęła turystów, stała się też źródłem wielu domysłów, prawdziwych rzekomo historii, krążących wśród mieszkańców miasta. Według jednej $\mathrm{z}$ opowieści nocami z głębi łajby dobiega szczekanie psa. Zgodnie $\mathrm{z}$ baskijskimi wierzeniami takie ujadanie mogło być złą wróżbą, zwiastującą śmierć [Douglas 2003: 45]. Jednak w nawiązaniu do historii owych rozbitków nie byłby to zły omen. Ci, którzy ocaleli, spotkali się bowiem z gościną miejscowych, niektórzy podobno osiedlili się nawet wśród tutejszej ludności, owszem w pewien sposób kończąc stare, ale i zaczynając nowe życie. Wydaje się to bliskie sytuacji wielu współczesnych imigrantów, których finałem podróży okazała się Kraina Euskary ${ }^{42}$.

41 Trudno o lepszą metaforę migracji niż łódź, tym bardziej, że określenia związane z marynistyką na stałe weszły do europejskiego dyskursu na temat migracji. Powszechnie mówi się więc o „fali”, „napływie” czy „zalewających nas” imigrantach, porównuje Europę do przepełnionej łodzi, a i na sam dźwięk słowa imigrant mamy przed oczyma prowizoryczne tratwy i łodzie, na których tłoczą się nieszczęśnicy marzący o lepszym życiu na europejskiej ziemi.

42 Nazwa Kraju Basków - Euskal Herria pochodzi od określenia Euskararen Herria, czyli 'Kraina Euskary'. 


\section{Bibliografia}

\section{Literatura cytowana}

Alvarez Enparantza José Luis (Txillardegui) (1997), Euskal Herria en el horizonte, Tafalla, Txalaparta.

Arana Williams Elena (1989), Basque Legends in Their Social Context, (w:) Essays in Basque Social Anthropology and History, William A. Douglas (red.), Reno, University of Nevada Press: 107-128.

Arriaga José Luis (2000), Euskal mitologia, Bilbao, Gero.

Arrizabalaga Marie-Pierre (2008), Las mujeres pirenaicas y la emigración en el siglo XIX, (w:) Mujer e emigración: una perspectiva plural, Julio Hernández Borge, Domingo L. González Lopo, Santiago de Compostela, Universidade de Santiago de Compostela: $107-132$.

Atxaga Bernardo (2009), El corcho y el ancla, (w:) Estudios culturales y de los medios de comunicación, María Pilar Rodríguez Pérez (red.), Bilbao, Universidad de Deusto: 123-138.

Azcárate Berriochoa Pedro (2013), Como un Jardín. El caserío guipuzcoano entre los siglos XIX y XX, Bilbao, Servicio Editorial de la Universidad del País Vasco.

Baglietto Pedro (2004) El drama de las víctimas del terrorismo, (w:) Gritos de libertad. 15 voces contra el terror de ETA y la hegemonía nacionalista, Madryt, La Esfera de los Libros: 115-127.

Cebolla Héctor, Requena Miguel (2009), Los inmigrantes marroquíes en España, (w:) Reher David- Sven, Requena Miguel (eds.), Las múltiples caras de la inmigración en España, Alianza Editorial, Madryt: 251-288.

Czykwin Elżbieta (2008), Dlaczego ludzie nie lubia „obcych” i „innych”? (w:) Czyżewski Krzysztof (red.), Warto zapytać o kulturę. Obcy, inny, swój, Białystok-Sejny, Urząd Marszałkowski Województwa Podlaskiego w Białymstoku, Ośrodek „Pogranicze - sztuk, kultur, narodów": 53-70.

Díez Rosa (2004) La paradoja vasca: democracia y terrorismo en el País Vasco, (w:) Gritos de libertad. 15 voces contra el terror de ETA y la hegemonía nacionalista, Madryt, La Esfera de los Libros: 89-101.

Douglass William A., Bilbao Jon (1986), Amerikanuak. Los vascos en el nuevo mundo, traducc. Larrañaga Román Basurto, Bilbao, Servicio Editorial Universidad del País Vasco.

Douglass William A. (2003), Muerte en Murélaga, tłum. z j. angielskiego Estrade Eduardo, Irun, Alberdania.

Egaña Iñaki (2009), Los crímenes de Franco en Euskal Herria 1936-1940, Tafalla, Txalaparta.

Eriksen Thomas Holland (2013), Etniczność i nacjonalizm. Ujęcie antropologiczne, Kraków, WUJ. 
Etxeberria Xabier (2001), La desobediencia civil como estrategia política, (w:) Enfoques de la desobediencia civil, Etxeberria Xabier (red.), Bilbao, Universidad de Deusto: 67-96.

Etxeberria Mauleon Xabier, Ruiz Vieytez Eduardo J., Vicente Torrado Trinidad L. (2007), Identidad islámica y espacio público en el País Vasco, Zarautz, Alberdania.

Fernández Montes Matilde (1996), Etnología de las comunidades autónomas, Madryt, Ediciones Doce Calles.

Fundación Progreso y Democracia (2014), A favor de España. El coste de la ruptura, Madryt, La Esfera de los Libros.

González Cayetano (2004), El País Vasco y los jóvenes espańoles, (w:) Gritos de libertad. 15 voces contra el terror de ETA y la hegemonía nacionalista, Madryt, La Esfera de los Libros: 9-24.

Ibarra Pedro, Zallo Ramón (2008), Introducción: Paz, democracia, libertades y derecho de decisión, (w): El País Vasco en sus encrucijadas. Diagnósticos y propuestas, Zallo Ramón (red.), Donostia, Ttartalo: 43-62.

Idoyaga Petxo (2008), Euskaldunon Egunkaria y „el estado de derecho”, (w:) El País Vasco en sus encrucijadas. Diagnósticos y propuestas, Zallo Ramón (coord.), Donostia, Ttartalo: 111-122.

Jáuregui Bereciartu Gurutze (1999), Basque Nationalism at a Crossroads, (w:) Basque Politics and Nationalism on the Eve of the Millennium, Reno, University of Nevada Press: 44-53.

Kindler Marta (2008), Transnarodowość. Nowe teorie migracji a wyzwania integracji imigrantów, (w): Problemy integracji imigrantów. Koncepcje, badania, polityki, Grzymała-Kazłowska Aleksandra, Łodziński Sławomir (red.), Warszawa, Wydawnictwa Uniwersytetu Warszawskiego: 51-71.

Kuligowski Waldemar (2012), Od „rytuałów buntu” do „etnografii wojujacej”. Kategoria sprzeciwu w teorii antropologicznej, (w:) Oblicza buntu. Praktyki i teorie sprzeciwu w kulturze współczesnej, Kuligowski Waldemar, Pomieciński Adam (red.), Poznań, Wydawnictwo Poznańskie: 19-43.

Kurlansky Mark (2000), The Basque history of the world, Londyn, Vintage.

Kunz Marco (2002), La Polonia en Getafe: Algún día, cuando pueda llevarte a Varsovia, de Lorenzo Silva, (w): Andres-Suárez Irene, Kunz Marco, d’Ors Inés, La inmigración en la literatura española contemporánea, Madryt, Editorial Verbum:165-184.

Lindner Rolf (2000), Durch Europa. In Berlin. Eine Einleitung, (w:) Lindner Rolf, Kumpe Christian (red.), Durch Europa. In Berlin. Porträts und Erkundungen, Berlin, BasisDruck: 9-18.

Manzanos Bilbao César (1999), El grito del otro: arqueología de la marginación racial, Bilbao, Editorial Tecnos.

Marín Escudero Pablo (2014), Cine documental e inmigración en España, Salamanca, Comunicación Social Ediciones y Publicaciones.

Martínez de Luna, Iñaki (2008), Diversidad identitaria en Euskal Herria (w:) El País Vasco en sus encrucijadas. Diagnósticos y propuestas, Zallo Ramón (red.), Ttartalo, Donostia: 415-422. 
Martínez María (2014), La educación de los „otros”: gestión de la diversidad y políticas interculturales en la escuela inclusiva vasca, (w:) De la identidad a la vulnerabilidad. Alteridad e integración en el País Vasco contemporáneo, Barcelona, Edicions Bellaterra: 71-111.

Modood Tariq (2014), Multikulturalizm, Poznań, Wydawnictwo Nauka i Innowacje.

Moreno Cabrera Juan Carlos (2015), Errores y horrores del españolismo lingüistico, Tafalla, Txalaparta.

Naïr, S. (2010), La Europa mestiza. Inmigración, ciudadanía, codesarrollo, Barcelona, Galaxia Gutenberg.

Navarro Joaquín (2003), Homenaje a Euskal Herria, Tafalla, Txalaparta.

Nowicka Ewa (2009), Dylematy pracy antropologa we współczesnym świecie, (w): Integralnokulturowe badanie kontaktu kulturowego. Wybrane problemy społeczne i prawne, Królikowska Jadwiga (red.), Warszawa, Wydawnictwa Uniwersytetu Warszawskiego: 17-32.

Pajares Miguel (2007), Inmigrantes del Este. Procesos migratorios de los rumanos, Barcelona, Icaria.

Pérez-Agote Alfonso (1999), The Future of Basque Identity, (w:) Basque Politics and Nationalism on the Eve of the Millennium, Reno, University of Nevada Press: 54-67.

Pomieciński Adam (2012), Ruch alterglobalny: między buntem a happeningiem, (w:) Oblicza buntu. Praktyki i teorie sprzeciwu w kulturze współczesnej, Kuligowski Waldemar, Pomieciński Adam (red.), Poznań, Wydawnictwo Poznańskie: 135-149.

Reher David- Sven, Requena Miguel (2009), Introducción: el impacto de la inmigración en la sociedad española, (w:) Reher David- Sven, Requena Miguel (red.), Las múltiples caras de la inmigración en España, Madryt, Alianza Editorial: 7-19.

Stallaert Christiane (1998), Etnogénesis y etnicidad en España: Una aproximación histórico-antropológica al casticismo, Barcelona, Anthropos editorial.

Totoriagüena Gloria Pilar (2004), Identity, Culture and Politics in the Basque Diaspora, Reno, University of Nevada Press.

Woodworth Paddy (2007), The Basque Country. A cultural history, Oxford, Signal Books. Vilar Pierre (1991), Historia Hiszpanii, Warszawa, Wydawnictwo Naukowe PWN.

Zuazo Koldo (2010), El euskera y sus dialectos. Origen, evolución y propuestas de futuro, Irun, Alberdania.

Zulaika Joseba (2011), Terrorismo y tabú: la remitificación terrorista, (w:) La cuestión vasca. Claves de un conflicto cultural y político, Josetxo Beriain, Roger Fernández Ubieta (red.), Barcelona, Anthropos: 87-93.

Żelazny Walter (2000), Francja wobec mniejszości narodowych. Etniczność, etnopolityka, etnosocjologia, Tyczyn, Wyższa Szkoła Społeczno-Gospodarcza.

\section{Inne źródła}

Joaquín Lecumberri Napal, Los dibujantes vascos homenajean a Muntañola $y$ a su personaje del TBO Josechu El Vasco, http://www.lavanguardia.com/cultu- 
ra/20120427/54285861909/dibujantes-vascos-homenajean-muntanola-tbo-josechu-el-vasco.html (19.03.2015).

Real Academia Española, Diccionario de la lengua española, http://lema.rae.es/dra$\mathrm{e} /$ ?val=vascuence (01.12.2014).

Teinteresa.es, http://www.teinteresa.es/noticias/ministro-Interior-medidas-terroristas-profesores_0_1049895754.html (04.03.2016).

Diccionario etimológico vasco, Michel Morvan,

http://projetbabel.org/basque/diccionario.php?q=etxe (04.03.2016).

Deia, José Basurto, Peluquerías interculturales para desmontar prejuicios

http://www.ikuspegi.eus/eus/prensa/entrada_prensa.php?id=78258 (05.03.2016).

Eustat, http://www.eustat.eus/elementos/ele0002700/ti_la-mitad-de-los-extranjeros-de-laca-de-euskadi-conviven-con-personas-de-nacionalidad-espanola/not0002718_c.html\#axzz422YBdrWO, (05.03.2016).

Eldiario.es, http://www.eldiario.es/norte/euskadi/Empleada-emigrante-expuesta-sexual -laboral_0_344015694.html, (12.01.2015).

Rapeando Migraciones Proyecto, http://rapeandomigraciones.tumblr.com/ (14.11.2015). 


\section{STRESZCZENIE}

Kraj Basków, z tradycyjnego obszaru emigracji stał się atrakcyjnym celem dla imigrantów. Jednocześnie mniejszościowy status, trwający wciąż konflikt z Madrytem, dwujęzyczny i wielokulturowy charakter regionu sprawiają, że sytuacja migracyjna przybyszy ma szczególny charakter. Wielu imigrantów często dopiero na miejscu poznaje tę specyfikę, która staje się dla nich integracyjnym wyzwaniem. Czy imigranci mieszkający w Baskijskiej Wspólnocie Autonomicznej odbierani/przedstawiani są przez społeczność miejscową jako kolejne niebezpieczeństwo dla „Zagrożonej kultury"?

Celem artykułu jest namysł nad charakterem relacji pomiędzy społecznością przybywającą i miejscową w Baskijskiej Wspólnocie Autonomicznej, a zwłaszcza nad sposobem postrzegania imigrantów przez tych ostatnich (w przeszłości i obecnie) i wyzwaniami stojącymi przed baskijską polityką integracyjną.

\section{Słowa kluczowe:}

Baskijska Wspólnota Autonomiczna, imigranci, mniejszość, kultura baskijska, integracja.

\section{SUMmaRY}

Traditionally, the Basque Country used to be a region where people emigrated from, but today it has become an attractive destination for immigrants. At the same time, the minority status of the Basque people, the ongoing conflict with Madrid, the bilingual and multicultural make-up of the region places the incoming migrants in singular circumstances. Many are confronted with that specificity only once they arrive, while integration becomes a genuine challenge. Are immigrants living in the Basque Autonomous Community seen by the local community as another threat to their "endangered culture"?

The aim of this article is to consider the nature of the relationship between local community and immigrants in the Basque Autonomous Community, with particular focus on the manner in which the latter are perceived by the Basques (in the past and at present) as well as reflect on the challenges facing Basque integration policy.

\section{Keywords:}

Basque Autonomous Community, immigrants, minority, Basque culture, integration. 